\title{
Impact of Irrigation Management on Shallow Groundwater Fluctuation and Soil Salinity: The Saltmed Model
}

\author{
A. A. Aly \\ Soil and Water Sciences Department, Faculty of Agriculture, \\ Alexandria University, Alexandria, Egypt.
}

\begin{abstract}
T SIWA OASIS, situated in Egypt, secondary salinization of irrigated lands is a crucial problem. The results found that the Siwa shallow groundwater (SGW) and high summer evapotranspiration is considered the main cause of soil salinization, however, the irrigation water sodicity is considered the main causes of soil sodicity. The SGW depth generally decreased in winter and increased in summer seasons. High correlation was found between the soil EC $\left(\mathrm{dS} \mathrm{m}^{-1}\right)$ and soil SAR and $\mathrm{Cl}$ (meq $\left.\mathrm{L}^{-1}\right)\left(\mathrm{R}^{2}=0.89\right.$ and 0.91 for $\mathrm{SAR}$ and $\mathrm{Cl}$, respectively), consequently, the dominant ions in Siwa soil solution are $\mathrm{Na}$ and $\mathrm{Cl}$. The results also emphasis good correlation between soil available nitrogen and SGW contamination with nitrate $\left(\mathrm{r}^{2}=0.80\right.$ and 0.73 , winter and summer, respectively). The eutrophication is expected in the study area especially in winter seasons due to nitrate concentrations increase. A conceptual, daily, semi-distributed hydrologic Saltmed model was found to be successful under Siwa climatic conditions. The model recorded that the quantity of irrigation water used in traditional irrigation is more than requirement. The traditional irrigation applies $300 \mathrm{~L} / \mathrm{m}^{2} / 14$ days, however, the quantity of $50 \mathrm{~L} / \mathrm{m}^{2} / 14$ days is adequate for olive crop water requirement and soil salinity removal. The results of this research could be applicable to similar situations worldwide.
\end{abstract}

Keywords: Soil salinity, Siwa oasis, Shallow groundwater, Saltmed model

Land degradation (LD) is defined as "the long-term loss of ecosystem function and services, caused by disturbances from which the system cannot recover unaided" (UNEP, 2007). Direct effects of the LD include losses of soil organic carbon, nutrients, soil water storage and regulation and belowground biodiversity, however, the indirect effects of LD include loss of the land's productive capacity and wildlife habitat and increase soil salinity. Soil deterioration is one critical aspect of LD, particularly of irreversible LD lead to desertification. Soil degradation is a consequence of depletive human activities and their interaction with natural environments, resulting in soil quality decline (Sawant et al., 2013). Lal and Stewart (1990) and Dregne (2002) distinguish three types of soil degradation, namely physical (e.g., soil erosion by wind and water), chemical (e.g., salinization and acidification) and biological (e.g., decline in soil organic matter). Although there is consensus that soil degradation is often a severe issue, there are few systematic measurements of its extent and severity (UNEP, 2007). Soils salinizations are found in all continents under agriculture; however, the 
salty soils are present most extensively in arid and semiarid regions of the world and cover approximately $7 \%$ of the total land area of the Earth (Ghassemi et al., 1995). Salt-affected soils occur as vast stretches of salt-encrusted lands or in small and isolated patches interspersed with normal soils, forming no contiguous pattern (Singh, 2005, Smedema and Shiati, 2002). Development of salty soil depends on climate, geology, soil mineral weathering, drainage, hydrology, irrigation source, ground water depth and quality and management practices (Ghassemi et al., 1995). Accumulation of sodium or neutral salts in soils over a period lead to formation of alkaline, saline-alkaline, or saline soils which may be compounded by natural or irrigation-induced factors, such as weathering of natural salt-bearing soil minerals, irrigation with saline, saline-alkaline, or alkaline waters and water logging due to a rising ground water table (Aly and Benaabidate, 2010). Salty soil including those that may also be water-logged, contain excessive concentrations of soluble neutral salts, and/or exchangeable sodium, which impairs seed germination and plant growth, and lead to poor crop yield. The major ionic composition of salty soil is $\mathrm{Ca}^{2+}, \mathrm{Mg}^{2+}, \mathrm{Na}^{+}, \mathrm{K}^{+}, \mathrm{HCO}_{3}^{-}$, $\mathrm{Cl}^{-}, \mathrm{NO}_{3}{ }^{-}$and $\mathrm{SO}_{4}{ }^{--}$(Aly and Benaabidate, 2010 and Chi \& Wang, 2010). To ensure sustainability, agriculture water users need to adopt improves water conservation strategies, develop new sources of water, and learn how to use lower quality water for irrigation. The water used for irrigation transfers salts to soils and also dissolves native salts, increasing soil salinity and decreasing crop yields. Excess irrigation water then must be applied to reduce salt build-up in the root zone (Ayars et al., 1993). Siwa Oasis, located in the western desert of Egypt, is today suffering from soil salinity and excessive rise of subsoil water levels. In 1962-1977, the rate of water table rise was $1.33 \mathrm{~cm}_{\text {year }}{ }^{-1}$; however, in 1977-1990 it measured $4.6 \mathrm{~cm}_{\text {year }}{ }^{-1}$ (Misak et al., 1997). Aly (2007) reported that the fertile soils in Siwa are subjected for deterioration and salinization dramatically due to water logging phenomena. The water table is thought to be rising throughout the oasis and the general rise is said to be more than $5.0 \mathrm{~cm}_{\text {year }}^{-1}$ (Aly, 2007). The main reasons of the high level of the groundwater and soil salinity in Siwa are the excessive use of saline water in irrigation depending mainly on flood irrigation, unusable discharge of some springs, as well as the uncontrolled drilling of wells and the agricultural expansion (Aly and Benaabidate, 2010 and Aly, 2007). To cope with the salinity and water logging problems, water use efficiency must be maximized and a national policy for using brackish water must be adopted. Models can be very useful tools in this respect. Not only can they help in calculating crop water requirements and irrigation scheduling but they can also be used to predict yields and soil salinization (Qingyun et al., 2007 and Selim, 2012). A successful water management scheme for irrigated crops needs a holistic approach that takes into account all water, crop, soil and field management. Most existing models are designed for a specific irrigation system, specific process such as water and solute movement, infiltration, leaching and water uptake by plant roots or a combination of them (Ragab, 2002). There is a shortage in models of a generic nature, models that can be used for a variety of irrigation systems, soil types, soil stratifications, crops and trees, water management strategies (blending or cyclic) leaching requirements and water quality. The SALTMED model (Ragab et al., $2005 \mathrm{a}, \mathrm{b}$ ) has been developed for

Egypt. J. Soil Sci. 54, No. 4 (2014) 
such an integrated approach. The model employs well-established equations of water and solute transport, evapotranspiration and crop water uptake. An early version of the SALTMED model was run using the tomato field data from Egypt and Syria during 2000-2002. The results showed very good agreement between the simulated and observed salinity data (Ragab et al., 2005 a, b). Recently, the model was successfully run using a sugar cane field experiment in Iran (Golabi et al., 2009) and on a number of field crops in Brazil (Montenegro et al., 2010). The 2009 version of the SALTMED model was compared against the field data of potatoes and tomatoes from Crete, Serbia and Italy using sub-surface drip irrigation, sprinkler irrigation and furrow irrigation as full irrigation and deficit irrigation systems. The model showed high capability to simulate soil salinity, moisture and nitrogen profiles, and dry matter and the final yield (Ragab, 2010).

The main objectives of this study is to a suggest suitable irrigation management of Siwa Ecosystem using Saltmed model to prevent shallow groundwater (SGW) level decrease, and soil salinity and sodicity increase.

\section{Material and Methods}

In this study the Siwa oasis was divided into the three locations Siwa city and surrounding, Aboshrof and El-Zytouna area, and El-Maraki area that cover all ecosystem soil type.

\section{Observation wells installation and analytical methods (Soil Analyses)}

Fifty three observation wells were installed according to Ravella et al. (1996), by auguring 3" $(7.5 \mathrm{~cm})$ diameter holes with a hand bucket auger to depths ranging from 1.5 to 2.0 meters, depending on the level of the water table at each site. A PVC pipes 2" $(5 \mathrm{~cm})$ diameter was used for each observation well. This made it quite convenient because we could fit these in the 3 " $(7.5 \mathrm{~cm})$ diameter hole. The observation wells were open at their bottoms, and slotted with a hacksaw all the way from their bottoms to a height above the water table. These observation wells were used to monitor the level and collect the shallow groundwater (SGW) samples. The water levels of each observation well at each site every month was monitored through year.

A hundred and six of surface and subsurface soil samples and fifty three SGW samples were collected from studied area. The soil samples were air dried, grounded, and passed through a $2 \mathrm{~mm}$ sieve, then stored for further analysis; however, the collected water samples were transported immediately to the laboratory in ice boxes for analyses (STM, 1998).

The soil paste extract was prepared, and the characterization of soil and SGW involved measuring chemical properties according to Page et al. (1982) and STM (1998) for soil and water, respectively.

The $\mathrm{pH}$ was determined by $\mathrm{pH}-$ meter (Jenco Electronics. LTD $\mathrm{pH}-$ Vision 6071) and the electrical conductivity, in deciseimens per meter, was measured by 
Baxter, Digital Conductivity Meter. Compleximetric EDTA titration was employed for determining calcium and magnesium simultaneously and individually (Lonoyn and Heald, 1982). Sodium and potassium was determined using flame photometer (Corning 400). Carbonate and bicarbonate were determined by titration with acid while silver nitrate was used to determine chloride Page et al. (1982). Soil available nitrogen was extracted by $2 \mathrm{M}$ potassium chloride and determined by stream distillation method (Kjeldahl apparatus) as described in Page et al. (1982). Nitrate in SGW were determined according to Matiti (2004).

Soil field capacity was determined by pressure cooker method with 0.3 atm pressure, as shown in Klute (1986) and the soil texture was determined by hydrometer methods according to Klute (1986).

Modeling study (SALTMED)

The SALTMED model version 3.02.08 was used on this study (Ragab, 2013).

\section{Model data requirements}

1. Plant characteristics include, crop coefficient, Kc, Kcb (Allen et al., 2000) root depth and lateral expansion, crop height and maximum and potential final yield observed in the region under optimum conditions.

2. Soil characteristics include depth of each soil horizon, saturated hydraulic conductivity, saturated soil water content, salt diffusion coefficient, longitudinal and transversal dispersion coefficient, initial soil moisture and salinity profiles, and tabulated data of soil moisture versus soil water potential and soil moisture versus hydraulic conductivity. Soil parameters such as water retention curves were based on laboratory measurements. Initial soil water content, shallow groundwater depth and salinity, and soil salinity were based on measurements either in laboratory or in the field.

3. Meteorological data include daily values of maximum temperature, minimum temperature, relative humidity, net radiation, wind speed, and daily rainfall. Those data were provided by the meteorological station of Siwa oasis, and National Climatic Data Center (online).

Siwa Oasis irrigation practices (KAP survey)

The basin irrigation system is the only irrigation method used in Siwa Oasis old farms. The irrigation basins are relatively small $\left(4 \times 4\right.$ or $\left.5 \times 5 \mathrm{~m}^{2}\right)$. Irrigation intervals in Siwa vary according to crop, soil type and growing season. In clay loamy soil planted with date palms, irrigation intervals varies from 16 days during summer to 20 days during winter, while in sandy soil, it varies from 8 to 10 days in summer and winter. In any case, the depth of water application is uncontrolled and variable, for example, if the irrigation waters requirements during 10 days interval is $75 \mathrm{~mm}$ in summer and $35 \mathrm{~mm}$ in winter, the practical application is usually $100 \mathrm{~mm}$ each irrigation all year around. This mean that the average amount of water applied throughout the year approaches 30,000 - 35,000

Egypt. J. Soil Sci. 54, No. 4 (2014) 
$\mathrm{m}^{3} /$ feddan, which is extremely higher than the capacity of the net drainage of the cultivated crops under the Siwa saline water and arid climate conditions.

\section{Results and Discussion}

Relation between $S G W$ depth and properties and soil chemical properties

Figure 1 showed that the SGW depth decreased in winter and increased in summer seasons due to high summer evapotranspiration, this finding is in agreement with the finding of Aly (2007) moreover, the Siwa city in Aghourmy area (observation wells 29 and 30) recorded the highest groundwater depth; however, the lowest depth was recorded in ElMaraki area near Elmaraki lake (observation well 42).

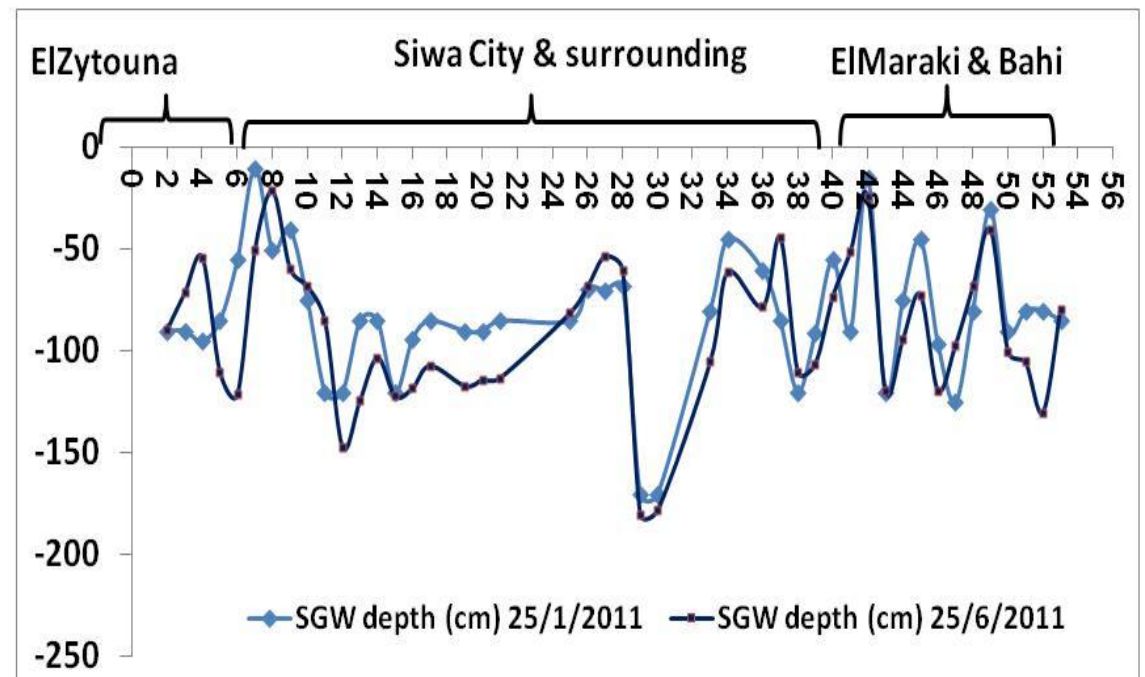

Fig. 1. Shallow groundwater (SGW) depth monitoring for Siwa Ecosystem in summer and winter.

This study recorded an inverse relationship between SGW depth and groundwater and soil salinity and sodicity, the lower the SGW depth the higher the groundwater and soil salinities and sodicities (Fig. $2 \mathrm{a}$ and b). This is due to more dynamic of soil water movement near soil surface since this is the surface where the soil water evaporation takes place, these findings are in agreement with Silva et al. (2012). The result also find high correlation between SGW salinity and soil salinity $\left(\mathrm{R}^{2}=0.85\right)$ on the other hand, no correlation was recorded between SGW SAR and soils SAR. This finding concluded that the high level of SGW is considered the main causes of soil salinity in Siwa Oasis, however, the irrigation water sodicity is considered the main causes of soil high value of SAR (Aly and Benaabidate, 2010). 
Figure 2 (c and d) showed high correlation between the Siwa soil EC $\left(\mathrm{dS} \mathrm{m}^{-1}\right)$ and soil $\mathrm{SAR}$ and $\mathrm{Cl}\left(\right.$ meq $\left.\mathrm{L}^{-1}\right)\left(\mathrm{R}^{2}=0.89\right.$ and 0.91 for $\mathrm{SAR}$ and $\mathrm{Cl}$, respectively), this mean that the dominant ions in Siwa soil solution were $\mathrm{Na}$ and $\mathrm{Cl}$. This is due the dominant ions on Siwa groundwater used for irrigation were $\mathrm{Na}$ and $\mathrm{Cl}$ (Aly and Benaabidate, 2010 and Shouse et al., 2010).

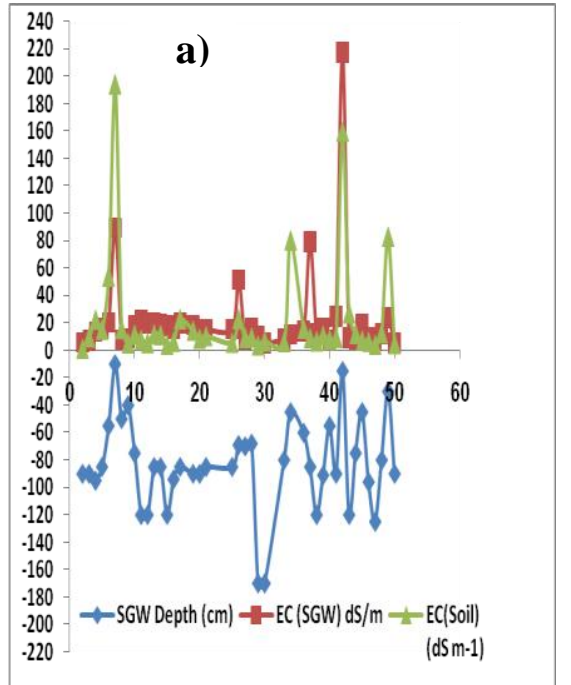

c) $\quad n=106$

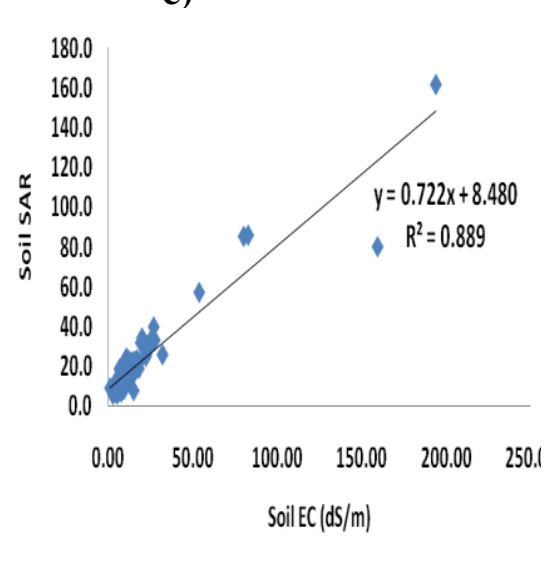

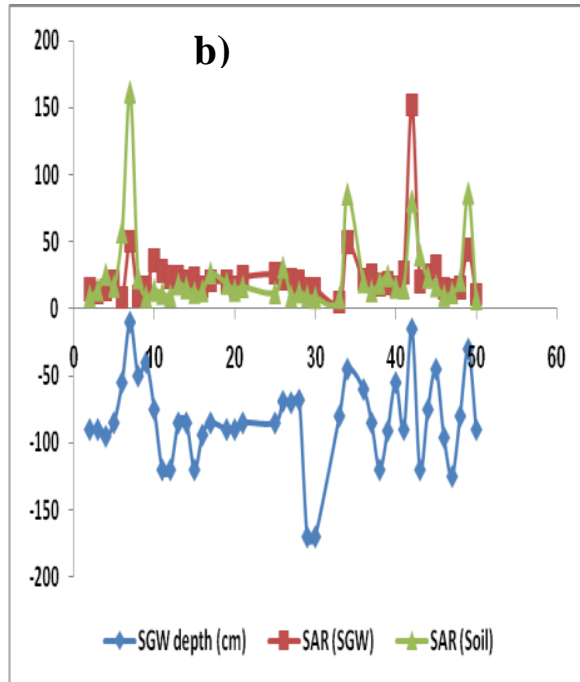

d) $n=106$

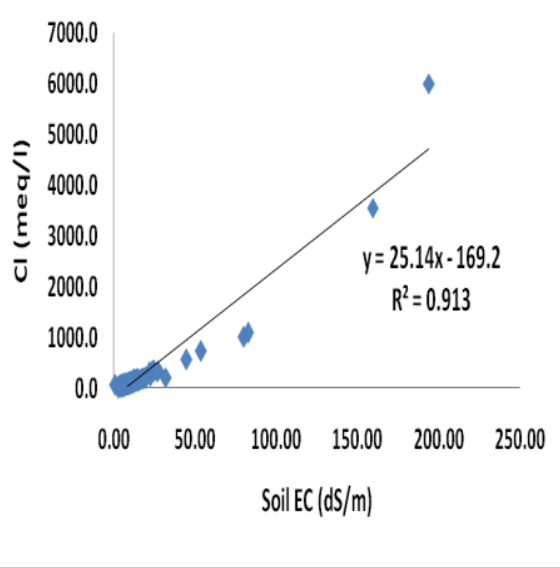

Fig. 2. The interrelationship and correlation between SGW depth, salinity and sodicity and soil salinity and sodicity .

Soil available nitrogen and SGW nitrate

Figure $3 \mathrm{a}$ and $\mathrm{b}$ concluded that the available soil nitrogen $\left(\mathrm{NH}_{4}, \mathrm{NO}_{2}\right.$ and $\left.\mathrm{NO}_{3}\right)$ increased on winter season to reach $510 \mathrm{mg} \mathrm{kg}^{-1}$ (sample no 19 in Siwa city) and

Egypt. J. Soil Sci. 54, No. 4 (2014) 
decreased on summer to be $100 \mathrm{mg} \mathrm{kg}^{-1}$ (sample no 4 and 13 in Siwa city). This is due to most farmers in Siwa oasis add nitrogen and manure to the soils as fertilizers on winter season in which olive and date palm trees needed nutrients. The results also emphasis good correlation between soil available nitrogen and SGW contamination with nitrate $\left(r^{2}=0.80\right.$ and 0.73 for winter and summer, respectively). Based on these results, we can expect that the Siwa drain is subject to be suffering from eutrophication, especially in winter seasons (Schelske and Stoermer, 1971, Schindler, 1971, Schindler, 1974 and Conleyl et al., 1993).
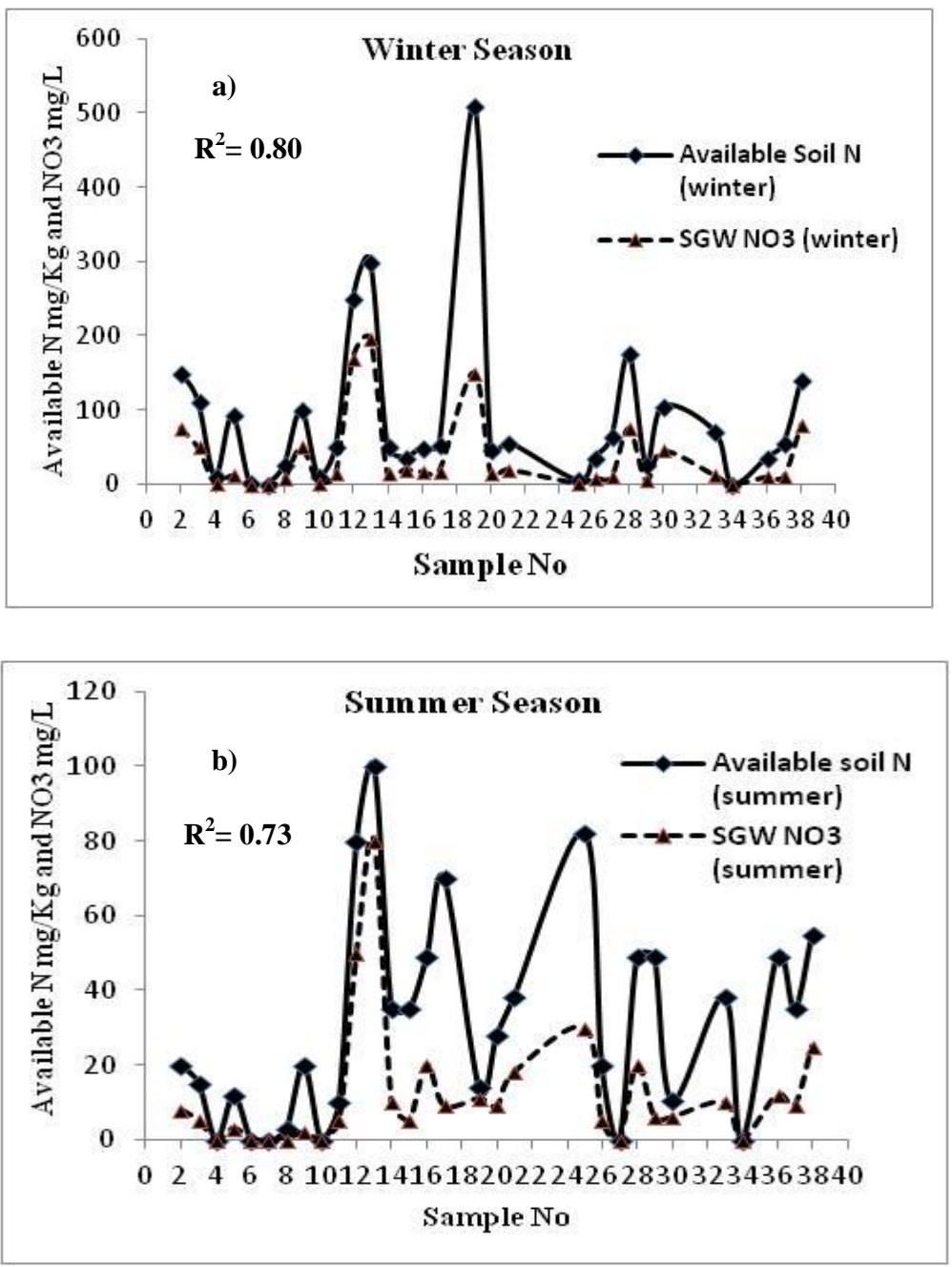

Fig. 3. Soil available nitrogen and $\mathrm{SGW} \mathrm{NO}_{3}$ concentrations on studied area . SALTMED model

In this study the SALTMED model was calibrated using the surface, basin, irrigation methods used in Siwa oasis, focused on soil salinity. After successful 
model calibration and validation, the model was run with hypothetical "what if" scenarios for better irrigation practices.

\section{Saltmed calibration and validation}

The Saltmed model calibration primarily focused on soil moisture and salinity of studied area. The validation process of soil salinity was based on use of the calibrated input parameters such as saturated and unsaturated hydraulic conductivity, leaf area index, crop height,...etc. Fine tuning of some crop and soil parameters was carried out in order to obtain a good calibration.

\section{i)Saltmed salinity calibration}

The calibration method aimed at adjusting the irrigation files contained soil parameters such as saturated and unsaturated hydraulic conductivity and plant parameters such as plant height and rooting depth, leaf area index, ...etc. until a minimal difference between observed and modeled salinity has been achieved. The calibrated Saltmed input of the control treatment was used in the validation of the other treatments.

The process of calibration was carried out first using the initial measured/estimated values of irrigation and soil parameters, then by gradually changing the values of the model parameters one at a time until the calibrated soil salinity is equal or near equal to the observed one.

ii)Saltmed salinity validation

Two type of model validation were carried out in Siwa as follow:

1.Surface soil salinity validation:

Ten randomized surface soil sample (three replicates for each location) were collected covering the Siwa Ecosystem. The soil paste extract was prepared for soil salinity measurement and also physical characteristics were carried out (Table 1).

2.Vertical "soil profile" salinity validation:

Samples of soil profiles were performed on three locations of Siwa cultivated areas, the three locations were, central of Siwa, Aboshrof area and El-Maraki area that cover all ecosystem soil type. Soil moisture, salinity and other characteristics were determined for each sample (Table 2).

\section{ii) Model simulation ability}

Figure $4 \mathrm{a}$ and $\mathrm{b}$ showed the correlation between observed and simulated soil salinity for surface and subsurface "soil profiles" Siwa soil. In general, the model showed very good agreement between the observed and simulated soil salinity. The correlation $\left(r^{2}\right)$ between the simulated and observed surface soil salinity is 0.81 , on the other hand, the $r^{2}$ of vertical distributions of soil salinity ranged between 0.55 in ElMaraki area and 0.98 in central Siwa and the $r^{2}$ of Aboshrof area was 0.90. Moreover, the model should good agreement between the observed and simulated SGW $\left(\mathrm{r}^{2}=\right.$ 0.71) (Fig. 5). These values are similar to those obtained by Hirich et al. (2012) and Silva et al. (2012).

"What if scenarios" using Saltmed model (soil salinity and irrigation amount)

Because the Saltmed model was successful under Siwa ecosystem climatic conditions and irrigation water qualities in different places throughout the Oasis,

Egypt. J. Soil Sci. 54, No. 4 (2014) 
there is substantial benefit in using this version of the model in improving irrigation practices by selecting better irrigation management that could be used in this fragile ecosystem. This model can help not only in irrigation scheduling, estimating crop water requirements and irrigation water conservation but can also be used to predict yields and soil salinization.

TABLE 1. Studied areas names, coordinates and soil properties.

\begin{tabular}{|c|c|c|c|c|c|c|c|}
\hline \multirow{2}{*}{$\begin{array}{c}\text { Serial } \\
\text { No }\end{array}$} & \multirow{2}{*}{ Key No } & \multicolumn{2}{|c|}{ Coordination } & \multirow{2}{*}{$\begin{array}{c}\text { Soil } \\
\text { EC }(d S / m)\end{array}$} & \multirow{2}{*}{$\begin{array}{l}\text { Water } \\
\text { content } \\
\left(\mathrm{m}^{3} / \mathrm{m}^{3}\right)\end{array}$} & \multirow{2}{*}{ FC } & \multirow{2}{*}{ Texture } \\
\hline & & $\mathbf{N}$ & $\mathbf{E}$ & & & & \\
\hline 1 & El-Zytouna & $29^{\circ} 9^{\prime} 50.4^{\prime \prime}$ & $25^{\circ} 46^{\prime} 24.4^{\prime \prime}$ & 7.79 & 0.05 & 0.08 & Sand \\
\hline 2 & Aboshrof1 & $29^{\circ} 11^{\prime} 23.8^{\prime \prime}$ & $25^{\circ} 44^{\prime} 46.4^{\prime \prime}$ & 11.17 & 0.10 & 0.07 & Sand \\
\hline 3 & Aboshrof2 & $29^{\circ} 11^{\prime} 9.8^{\prime \prime}$ & $25^{\circ} 44^{\prime} 29.0^{\prime \prime}$ & 11.35 & 0.12 & 0.10 & Loamy Sand \\
\hline 4 & Northern Siwal & $29^{\circ} 14^{\prime} 54^{\prime \prime}$ & $25^{\circ} 34^{\prime} 6.8^{\prime \prime}$ & 5.40 & 0.09 & 0.11 & Loamy Sand \\
\hline 5 & Western Siwa & $29^{\circ} 12^{\prime} 25.0^{\prime \prime}$ & $25^{\circ} 30^{\prime} 34.7^{\prime \prime}$ & 12.30 & 0.06 & 0.06 & Sand \\
\hline 6 & Central of Siwa & $29^{\circ} 12^{\prime} 27.2^{\prime \prime}$ & $25^{\circ} 31^{\prime} 59.4^{\prime \prime}$ & 4.70 & 0.07 & 0.07 & Sand \\
\hline 7 & Northern Siwa2 & $29^{\circ} 14^{\prime} 11.1^{\prime \prime}$ & $25^{\circ} 33^{\prime} 30.7^{\prime \prime}$ & 5.83 & 0.08 & 0.09 & Loamy Sand \\
\hline 8 & Maraki & $29^{\circ} 13^{\prime} 31.9^{\prime \prime}$ & $25^{\circ} 23^{\prime} 26.4^{\prime \prime}$ & 10.75 & 0.09 & 0.07 & Sand \\
\hline 9 & Bahi Eldean1 & $29^{\circ} 15^{\prime} 16.2^{\prime \prime}$ & $25^{\circ} 20^{\prime} 26.1^{\prime \prime}$ & 10.51 & 0.20 & 0.11 & Loamy Sand \\
\hline 10 & Bahi Eldean2 & $29^{\circ} 16^{\prime} 12.6^{\prime \prime}$ & $25^{\circ} 18^{\prime} 36.3^{\prime \prime}$ & 5.33 & 0.25 & 0.11 & Loamy Sand \\
\hline
\end{tabular}

TABLE 2. Some soil parameters used by Saltmed model .

\begin{tabular}{|c|c|c|c|c|c|c|c|c|}
\hline \multirow{2}{*}{$\begin{array}{l}\text { Area } \\
\text { Name }\end{array}$} & \multirow[b]{2}{*}{ Depth (m) } & \multicolumn{3}{|c|}{ EC (dS/m) } & \multirow{2}{*}{\begin{tabular}{|c|} 
SGW \\
depth \\
(m)
\end{tabular}} & \multirow{2}{*}{$\begin{array}{c}\begin{array}{c}\text { Water } \\
\text { content } \\
\left(\mathrm{m}^{3} / \mathrm{m}^{3}\right)\end{array} \\
\end{array}$} & \multirow[b]{2}{*}{ FC } & \multirow[b]{2}{*}{ Texture } \\
\hline & & \begin{tabular}{|l|} 
Soil \\
Paste
\end{tabular} & SGW & Well & & & & \\
\hline \multirow{3}{*}{$\begin{array}{l}\text { Central of } \\
\text { Siwa }\end{array}$} & $0-0.3$ & 5.83 & \multirow{3}{*}{8.06} & \multirow{3}{*}{5.41} & \multirow{3}{*}{0.8} & 0.07 & 0.06 & Sand \\
\hline & $0.3-0.6$ & 5.74 & & & & 0.13 & 0.07 & Sand \\
\hline & $0.6-0.9$ & 7.04 & & & & 0.17 & 0.06 & Sand \\
\hline \multirow{4}{*}{$\begin{array}{l}\text { Aboshrof1 } \\
\text { Siwa }\end{array}$} & $0-0.3$ & 11.17 & \multirow{4}{*}{19.17} & \multirow{4}{*}{9.8} & \multirow{4}{*}{1.2} & 0.25 & 0.08 & $\begin{array}{l}\text { Loamy } \\
\text { Sand }\end{array}$ \\
\hline & $0.3-0.6$ & 8.74 & & & & 0.37 & 0.09 & $\begin{array}{l}\text { Loamy } \\
\text { Sand } \\
\end{array}$ \\
\hline & $0.6-0.9$ & 13.37 & & & & 0.64 & 0.08 & $\begin{array}{l}\text { Loamy } \\
\text { Sand }\end{array}$ \\
\hline & $0.9-1.2$ & 13.26 & & & & 0.48 & 0.09 & $\begin{array}{l}\text { Loamy } \\
\text { Sand } \\
\end{array}$ \\
\hline \multirow{3}{*}{$\begin{array}{l}\text { El-Maraki } \\
\text { Bahi } \\
\text { (Eldean2, } \\
\text { Siwa) }\end{array}$} & $0-0.3$ & 5.33 & \multirow{3}{*}{8} & \multirow{3}{*}{5.11} & \multirow{3}{*}{0.9} & 0.53 & 0.08 & Sand \\
\hline & $0.3-0.6$ & 3.52 & & & & 0.25 & 0.06 & Sand \\
\hline & $0.6-0.75$ & 4.06 & & & & 0.31 & 0.07 & Sand \\
\hline
\end{tabular}

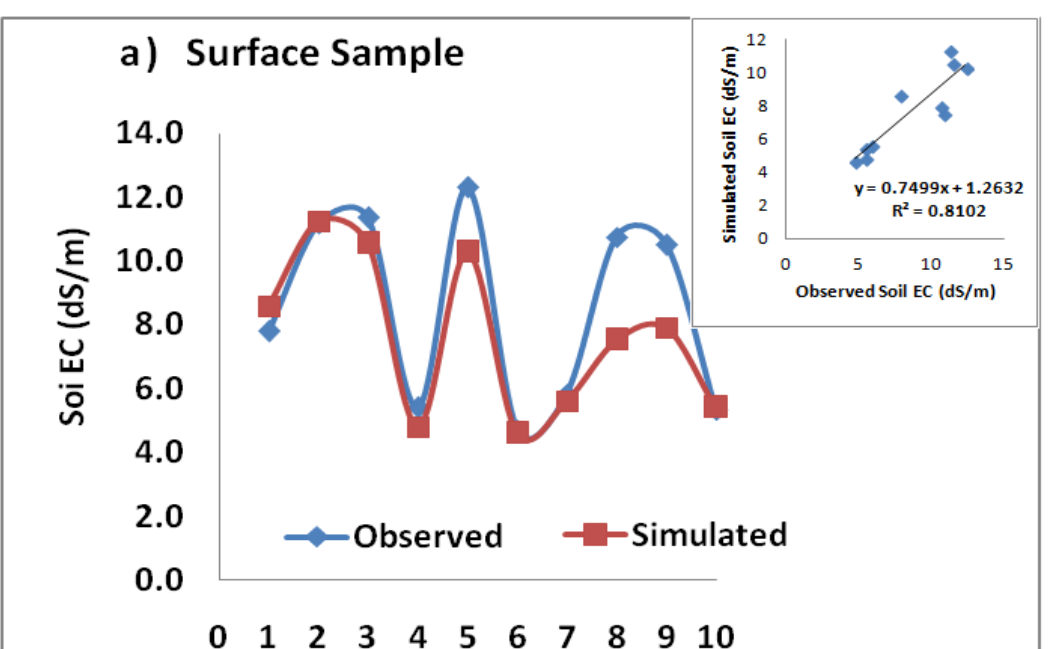




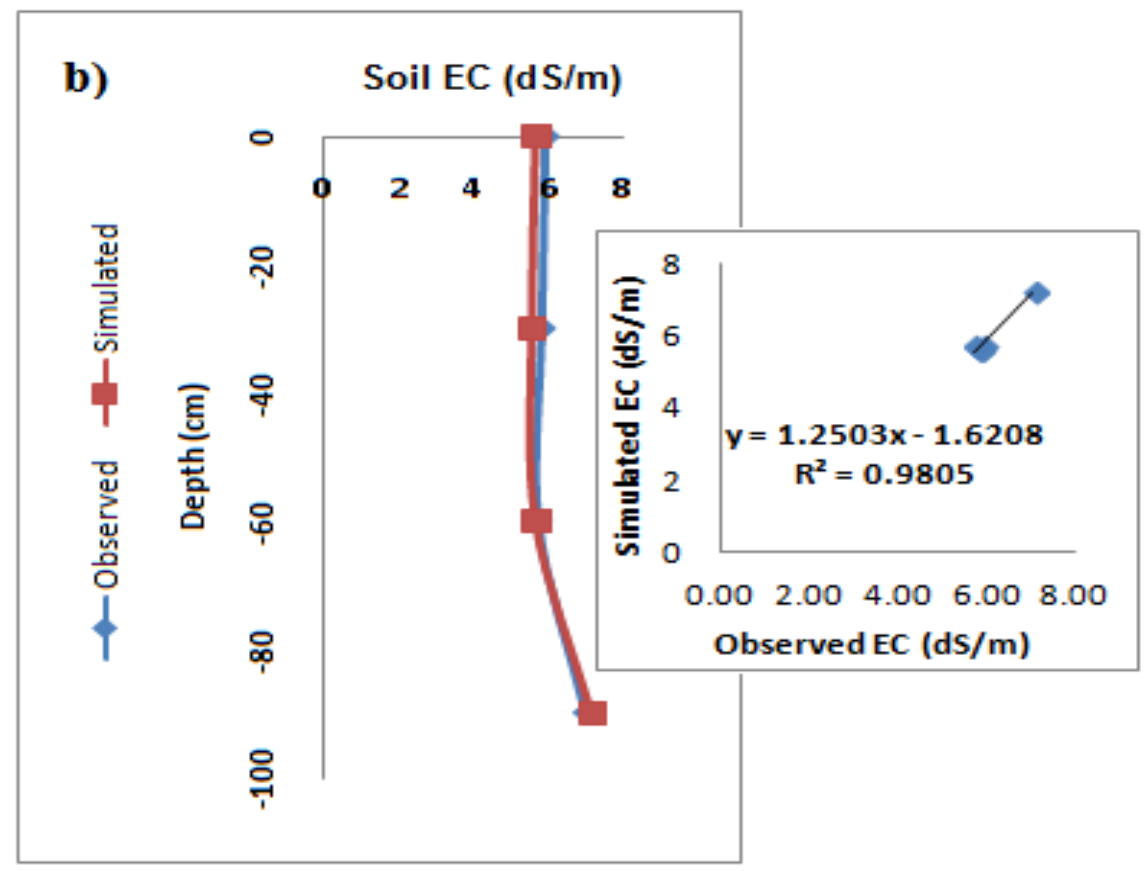

Fig. 4. Correlation between observed and simulated soil EC (dS/m) of: a) surface soil samples covered different areas of Siwa oasis b) Verticale soil sample (profile) of central Siwa .

Egypt. J. Soil Sci. 54, No. 4 (2014) 


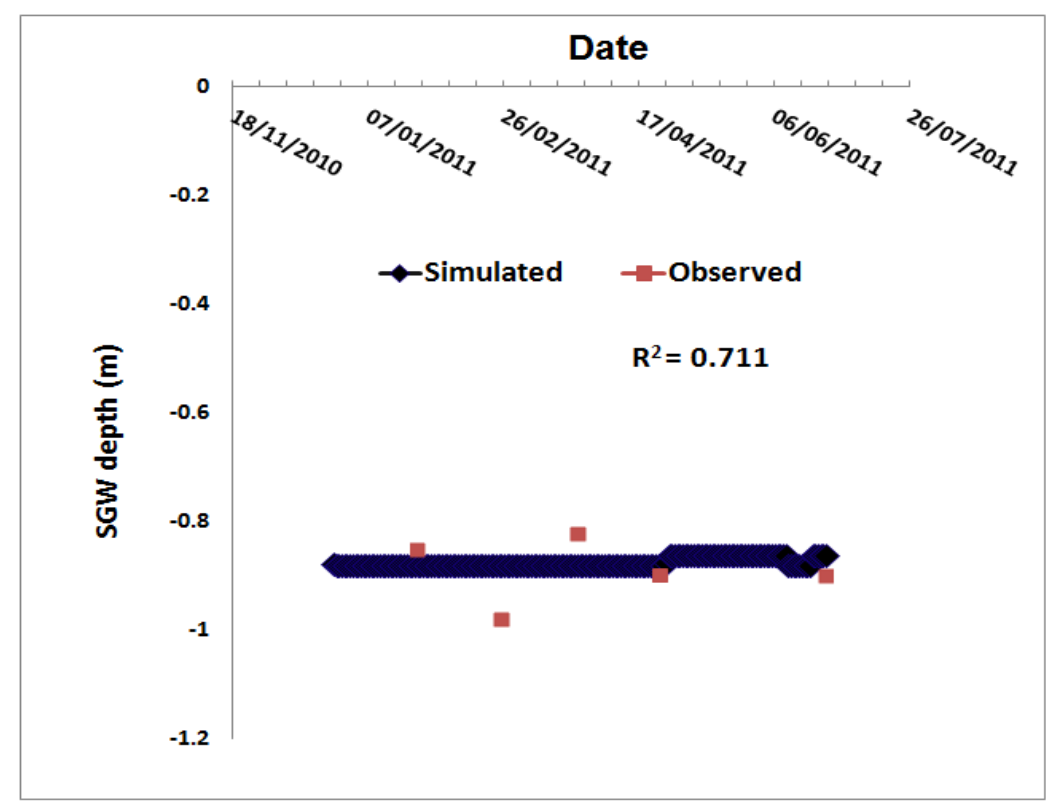

Fig. 5. Observed and Simulated SGW depth in Siwa oasis using Saltmed model .

The central Siwa land was selected for this part of the study, the model was run with six hypothetical and one actual amount of irrigation water 300, 200, 100, $50,25,10$ and 0 (L/m $/ 14$ days) (using same area and conditions). As it is clear in Fig. 6, the Siwan farmers add excess amount of irrigation water than crop and soil needed. The Siwan farmers add amount of irrigation water equal $300 \mathrm{~L} / \mathrm{m}^{2} / 14$ days, this amount was more than the amount required for olive crop and soil salinity removal (Fernandez et al., 1992 and Fernandez \& Moreno, 1999). The model result concluded that the irrigation amount of $50 \mathrm{~L} / \mathrm{m}^{2} / 14$ days gives same soil salinity distribution as in case of using $300 \mathrm{~L} / \mathrm{m}^{2} / 14$ days. On the other hand, the amount of irrigation water less than this quantity will lead to increase soil salinization (Fig. 6). This is due to capillary flux from saline shallow groundwater will takes places in the conditions of low precipitation and high evapotranspiration as the Siwa conditions. In case of no irrigation water $\left(0 \mathrm{~L} / \mathrm{m}^{2} / 14\right.$ days $)$, the soil salinity increased rapidly causing secondary surface soil salinization and as a consequence rapid ecosystem deterioration is expected (Fig. 6) (Allen et al., 2000).

iv) Impact of Irrigation amount on water table fluctuation using Saltmed model

According to Saltmed model results (Fig. 7a), no difference was observed in SGW level in case of using irrigation amount of 300 or $50 \mathrm{~L} / \mathrm{m}^{2} / 14$ days, in the presence of good drainage system (i.e., open drains ditches with bottom breadth of $0.75 \mathrm{~m}$ ). However, if drains efficiency decreases (i.e., using tile drainage with pipe diameter of $40 \mathrm{~mm}$ ) the SGW level started decreases by using 300 $\mathrm{L} / \mathrm{m}^{2} / 14$ days (Fig. 7 b). 


\section{Salinity (dS/m)}

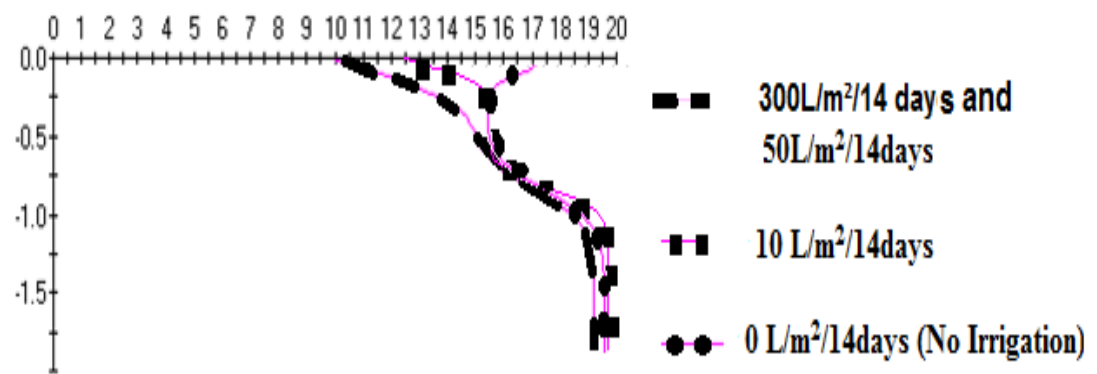

\section{Depth below Soil Surface}

Fig.6. Distribution of soil salinity on soil profile of Siwa city using Saltmed model with different irrigation scenarios .

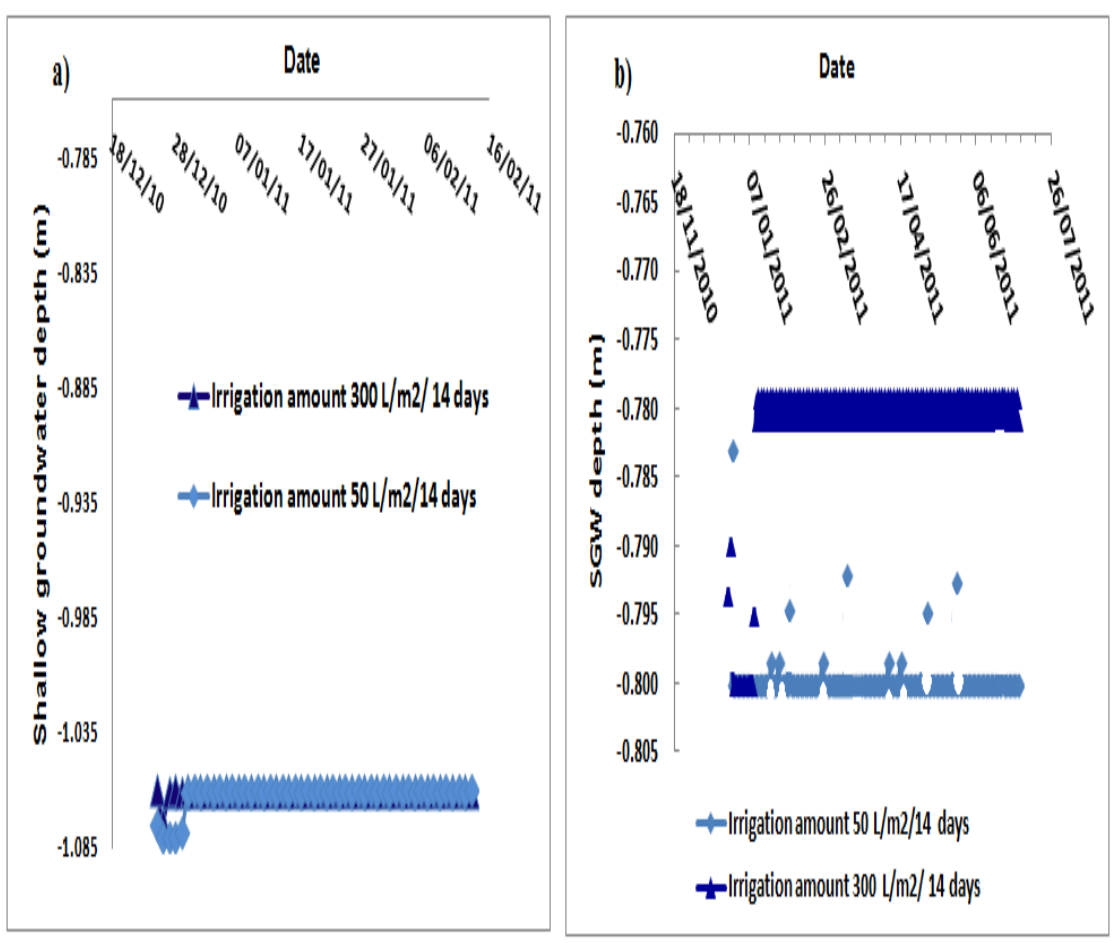

Fig.7. Saltmed model simulation to study the impact of irrigation amount in SGW depth under a) actual drainage system (open ditches) and b) Subsurface drainage system assuming $40 \mathrm{~mm}$ pipe diameters .

Egypt. J. Soil Sci. 54, No. 4 (2014) 


\section{Conclusion}

This study concluded that the Siwa ecosystem shallow groundwater (SGW) depth in summer is lower than in winter; on the other hand, the soil salinity is higher in summer than in winter. There is an inverse relationship between soil salinity and SGW depth (deeper SGW = lower soil salinity). The Siwa soil salinity and SAR were found to be highly correlated. The Saltmed model was successful under Siwa oasis ecosystem climatic conditions and irrigation water qualities in different places throughout the oasis. There were very good agreement between simulated and observed soil salinity and SGW depth, in most cases the $\mathrm{R}^{2}$ was over $80 \%$ for surface soil salinity and $71 \%$ for SGW depth. By using the Saltmed for irrigation water management, it was found that the quantity of irrigation waters used by Siwan farmers are more than needed $300 \mathrm{~L} / \mathrm{m}^{2} / 14$ days and the quantity of irrigation waters of $50\left(\mathrm{~L} / \mathrm{m}^{2} / 14\right.$ days $)$ are considered to be adequate for olive requirement and soil salinity removal, furthermore, the model concluded that the using of $300 \mathrm{~L} / \mathrm{m}^{2} / 14$ days does not enhance soil salinity reduction, but reduces the shallow groundwater depth in the conditions of poor drainage system. More work must be undertaken for determining water requirements, and thereby irrigation scheduling for the Siwa Oasis.

Acknowledgement: The authors would like to acknowledge with thanks the financial support of the Agricultural Research and Development Fund (ARDF) within the Eco-Siwa project. Thanks also for Prof. Ragab Ragab, Centre for Ecology and Hydrology $(\mathrm{CEH})$, Wallingford OX10 $8 \mathrm{BB}$, UK for help in modeling part.

\section{References}

Allen Richard, G., Pereira, L.S., Raes, D. and Smith M. (2000) Crop Evapotranspiration (guidelines for computing crop water requirements). FAO Irrigation and Drainage Paper 56, 326.

Aly, A. (2007) A Holistic ecosystem approach for sustainable management of land and water resources in Siwa Oasis. Ph. D. Thesis, Faculty of Agriculture, Alexandria University, Egypt.

Aly, A.A. and Benaabidate, L. (2010) Salinity of water resources in the Siwa Oasis: Monitoring and diagnosis. "Water-Rock Interaction", Brikle \& Torres Alvaro (Ed.), Taylor \& Francis Group, London.

Ayars, J.E., Hutmacher, R.B., Schoneman, R.A., Vale, S.S., and Pllaum, T. (1993) Long term use of saline water for irrigation. Irrig. Sci. 14: 27-34.

Chi, C. and Wang, Z. (2010) Characterizing salt-affected soils of songnen plain using saturated paste and 1:5 soil-to-water extraction methods. Arid Land Research and Management 24:1-11.

Conleyl, D.J., Schelske, C.L. and Stoermer, E.F. (1993) Modification of the biogeochemical cycle of silica with eutrophication. Mar. Ecol. Prog. Ser. 101: 179-192.

Egypt. J. Soil Sci. 54, No. 4 (2014) 
Dregne H.E. (2002) Land degradation in the drylands. Arid Land Res.\&Manag. 16 (2): 99-132.

Fernandez, J.E. and Moreno, F. (1999) Water use by olive tree. Journal of Crop Production 2(2): 101-162.

Fernandez, J.E., Moreno, F., Martin-Aranda, J. and Fereres E. (1992) Olive tree root dynamics under different soil water regimes. Agr. Med. 122: 225-235.

Ghassemi, F., Jakeman, A.J. and Nix, H.A. (1995) Salinization of land and water resources: Human causes, extent, management and case studies. CAB International, Wallingford, UK.

Golabi, M., Naseri, A.A. and Kashkuli, H.A. (2009) Evaluation of SALTMED model performance in irrigation and drainage of sugarcane farms in Khuzestan province of Iran. J. of Food, Agric. \& Enviro.7 (2): 874-880.

Hirich, A., Choukr-Allah, R., Ragab, R., Jacobsen, S.E., El- Youssfi, L. and ElOmari, H. (2012) The SALTMED model calibration and validation using field data from Morocco. J Mater Environ. Sci. 3(2): 342-359.

Klute, A. (1986) "Methods of Soil Analysis", Part 1, $2^{\text {nd }}$ ed., Agron Monor. 9, ASA and SSSA, Madison, WI.

Lal, R. and B. Stewart, (1990) "Soil Degradation: A Global Threat", Springer-Verlag, New York.

Lonyon, L.E. and Heald, W. R. (1982) Magnesium, calcium, Strantium and barium. In: "Methods of Soil Analysis, Part 2, Chemical and Microbiological Properties", A.L. Page et al. (Ed.), Agronomy Monograph no. 9, $2^{\text {nd }}$ ed., ASA-SSSA, Madisen, WI, USA.

Matiti, S.K. (2004) "Handbook of Methods in Environmental Studies: Water and Wastewater Analysis", ABD Publishers, Jaipur (India).

Misak, R.F., Abdel Baki, A.A. and El-Hakim, M.S. (1997) On the casuses and control of the waterlogging phenomenon, Siwa Oasis, Western Desert. J. of Arid Enviro. 37: 23-32.

Montenegro, S.G., Montenegro, A. and Ragab, R. (2010) Improving agricultural water management in the semi-arid region of Brazil: experimental and modelling study. Irrigation Science 28: 301-316. .Moutonnet, P., 2000. Yield Response to Field Crops to Deficit Irrigation In Deficit irrigation practices. C. Kirda et al. (Ed.), Water Report \#22 FAO, Rome.

Page, A.L., Miller, R.H. and Keenery, D.R (1982) "Methods of Soil Analysis Part 2: Chemical and Micro- Biological Properties", Am Soc. Agron., Madison, Wisconsin, USA. 
Qingyun, Z., Shaozhong, K., Lu, Z. and Fusheng, L. (2007) Comparison of APRI and Hydrus-2D models to simulate soil water dynamics in a vineyard under alternate partial root zone drip irrigation. Plant Soil 291: 211-223.

Ragab, R. (2002) A holistic generic integrated approach for irrigation, crop and field management: the SALTMED model. Environmental Modelling \& Software 17(4): 345-361.

Ragab, R.( 2010) SALTMED model as an integrated management tool for water, crop, soil and fertilizers. Manejo da salinidade na agricultura: Estudos básicos e aplicados. INCTSal. Fortaleza - CE. 2010. Available on line.

Ragab, R. (2013) The SALTMED model. Centre for Ecology and Hydrology, CEH, UK (personal communication).

Ragab, R., Malash, N., Abdel Gawad, G., Arslan, A. and Ghaibeh, A. (2005a) A holistic generic integrated approach for irrigation, crop and field management: 1 . The SALTMED model and its calibration using field data from Egypt and Syria. Agric. Water Manag. 78(1-2): 67-88.

Ragab, R., Malash, N., Abdel Gawad, G., Arslan, A. and Ghaibeh, A. (2005b) A holistic generic integrated approach for irrigation, crop and field management: 2 . The SALTMED model validation using field data of five growing seasons from Egypt and Syria. Inter. J. of Agric.Water Manag. 78 (1-2): 89-107.

Ravella, M., Lance, D. and Tim, A. (1996) Potential aquifer recharges locations in the keeme.

Sawant, R.S., Jadhav, S.D. and Godghate, A.G. (2013) Spatial variation in soil fertility along the bank of hiranykeshi river from Gadhinglaj Tahsil with reference to sugar cane field. Inter. J. of Science, Enviro. and Techno.2(4): $765-771$

Schelske, C.L. and Stoermer E.F. (1971) Eutrophication, silica depletion, and predicted changes in algal quality in Lake Michigan. Soil Science 173: $423-424$.

Schindler, D.W. (1974) Eutrophication and recovery in experimental lakes: implications for lake management. Science 184: 897-899.

Schindler, D.W. (1971) Carbon, nitrogen and phosphorus and the eutrophication of freshwater lakes. J. Phycol. 7: 321-329

Selim,T. (2012) Influence of geometric design of alternate partial root-zone subsurface drip irrigation (APRSDI) with brackish water on soil moisture and salinity distribution. Agric. Water Manag. 103: 182 - 190.

Shouse, P.J., Goldberg, S., Skaggs, T.H., Soppe, R.W.O. and Ayars, J.E. (2010) Changes in spatial and temporal variability of SAR affected by shallow groundwater management of an irrigated field, California. Agric. Water Manag. 97: 673-680

Silva, L.L., Ragab, R., Duarte, Lourenc, I.O.E., Simo es, N. and Chaves, M.M. (2012) Calibration and validation of SALTMED model under dry and wet year conditions using chickpea field data from Southern Portugal. Irrig. Sci. DOI 10.1007/s00271-0120341-5. 
Singh, N.T. (2005) "Irrigation and Soil Salinity in the Indian Subcontinent: Past and Present", Lehigh Univ. Press, Bethlehem, PA.

Smedema, L.K. and Shiati, K. (2002) Irrigation and salinity: A perspective review of the salinity hazards of irrigation development in the arid zone. Irrig. Drainage Syst. 16:161-174.

Standard Methods (STM), American Puplic Health Association (APHA). (1998) Standard methods for the examination of water and wastewater, $20^{\text {th }}$ ed., American Public Health Association, Washington, DC.

UNEP. (2007) GEO-4: Global environmental outlook. Environment for development. United Nations Environ. Programme, Nairobi.

(Received 6/4/2014; accepted 8/6/2014) 


\section{تاثير إدارة الرى على تذبذب المياه الجوفية وملوحة التربة: برنامج}

واحة سيوه الو اقعة فى مصر تعانى من التملح الثانوى ويشكل ذلك مشكة خطيره.

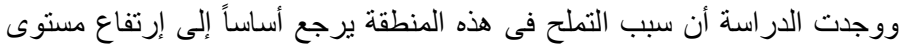

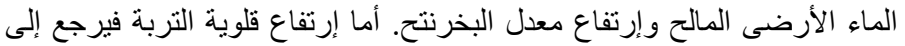

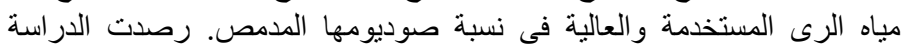

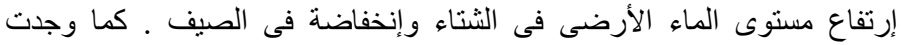

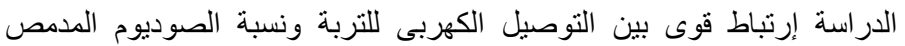

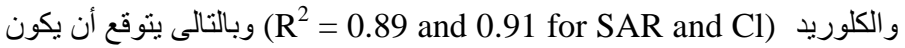

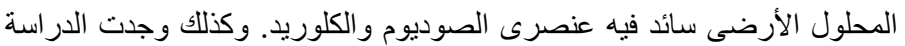

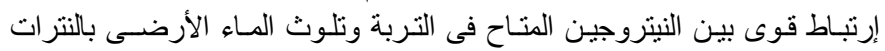

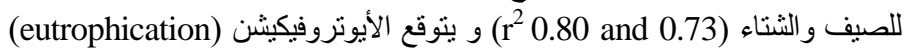

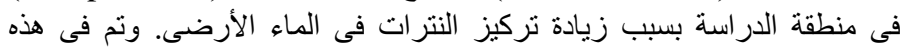

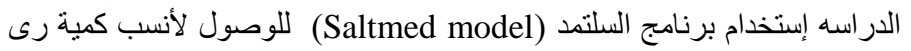
يمكن بها التظلب على الملوحة. فى الواقع تم إختبار صلاحية البرنامج فى ظلى لإنل

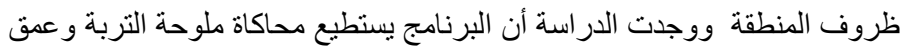

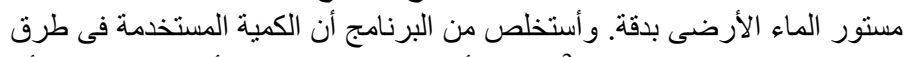

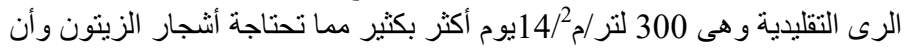

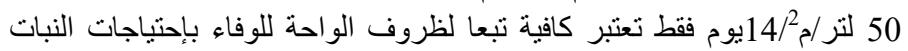

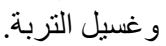


